\title{
Pengaruh Waktu Steam Blanching dan Suhu Pengeringan terhadap Karakteristik Kimia Serta Sensori Teh Daun Bambu Tabah (Gigantochloa nigrociliata BUSE-KURZ)
}

\section{Effect of Steam Blanching Time and Drying Temperature towards the Characteristics of Chemistry and Sensory of Bamboo "Tabah" Leaf Tea (Gigantochloa nigrociliata BUSE-KURZ)}

\author{
I Nyoman Cahyadi Purnama, Pande Ketut Diah Kencana*, I Made Supartha Utama \\ Program Studi Teknik Pertanian, Fakultas Teknologi Pertanian Universitas Udayana, Badung, Bali, \\ Indonesia \\ *E-mail: diahkencana@unud.ac.id
}

\begin{abstract}
Abstrak
Bambu "Tabah" adalah salah satu varietas bambu yang hanya ditemukan di pulau Bali. Daun bambu "Tabah" berpotensi untuk dikembangkan sebagai bahan baku pembuatan teh yang mampu menghasilkan minuman dengan berbagai khasiat. Jika dimanfaatkan secara optimal daun bambu "Tabah" dapat diolah sebagai suatu produk yang nantinya memberikan suatu keuntungan. Penelitian ini bertujuan untuk mengetahui pengaruh steam blanching dan proses pengeringan terhadap aktivitas kadar air, $\mathrm{pH}$, total asam, total fenol, dan organoleptik teh daun bambu "Tabah". Daun bambu "Tabah" diberi perlakuan waktu steam blanching dengan variasi waktu yaitu selama 10 menit, 15 menit, dan 20 menit. Setelah di steam blanching, daun bambu "Tabah" dikeringkan dengan menggunakan oven dengan variasi suhu pengeringan yaitu $50^{\circ} \mathrm{C}$, $60^{\circ} \mathrm{C}$, dan $70^{\circ} \mathrm{C}$. Metode penelitian yang digunakan adalah metode eksperimen dengan Rancangan Acak Lengkap (RAL) pola faktorial yang terdiri dari dua faktor dan diulang tiga kali. Faktor pertama adalah waktu steam blanching dan faktor yang kedua adalah suhu pengeringan. Hasil penelitian menunjukan bahwa kombinasi perlakuan terbaik berdasarkan uji hedonik penerimaan keseluruhan yang dihasilkan pada teh daun bambu "Tabah" yaitu pada perlakuan waktu steam blanching 15 menit dengan suhu pengeringan $60^{\circ} \mathrm{C}$ (W2S2) yang menghasilkan kadar air 7,03\% untuk SNI kadar air teh yaitu 8\%, nilai pH 6,40, nilai total asam $0,94 \%$, kadar total fenol $54,95 \mathrm{mg} / 100 \mathrm{~g}$, uji skoring warna 4,47 , uji skoring aroma 4,87 , uji skoring rasa 4,60 dan uji hedonik penerimaan keseluruhan 4,67.
\end{abstract}

Kata kunci: steam blanching, pengeringan, teh bambu Tabah

\begin{abstract}
Bamboo "Tabah" is one of the bamboo variety of which finds only in Bali island. "Tabah" bamboo leaves have the potential to be developed as raw materials for making tea that can produce drinks with various benefits. If utilized optimally, "Tabah" bamboo leaves can be processed as a product that will provide an advantage. This study aims to determine the effect of steam blanching and drying process on the activity of water content, $\mathrm{pH}$, total acid, total phenol, and organoleptic " Tabah" bamboo leaf tea. "Tabah" bamboo leaves are treated with steam blanching time with a variation of time, namely for 10 minutes, 15 minutes and 20 minutes. After steam blanching, the "Tabah" bamboo leaves are dried using an oven with variations in the drying temperature of $50^{\circ} \mathrm{C}, 60^{\circ} \mathrm{C}$ and $70^{\circ} \mathrm{C}$. The research method used was an experimental method with a completely randomized design (CRD) factorial pattern consisting of two factors and repeated three times. The first factor is the steam blanching time and the second factor is the drying temperature. The results showed that the best combination of treatments based on the overall acceptance of hedonic tests produced on "Tabah" bamboo leaf tea is the treatment of 15 minutes steam blanching time with a drying temperature of $60^{\circ} \mathrm{C}$ (W2S2) which produces $7.03 \%$ water content for SNI water content $8 \%$, pH value 6.40 , total acid value $0.94 \%$, total phenol content $54.95 \mathrm{mg} / 100 \mathrm{~g}$, color scoring test 4.47 , aroma scoring test 4.87 , taste scoring test 4.60 and overall acceptance hedonic test 4,67.
\end{abstract}

Words key: steam blanching, drying, tea bamboo"Tabah"

\section{PENDAHULUAN}

Bambu merupakan tanaman berumpun, termasuk dalam suku Gramineae. Tanaman ini tumbuh tersebar di daerah tropis, sub tropis dan daerah beriklim sedang. Terdapat \pm 40 jenis bambu tumbuh di Bali dari 161 jenis bambu yang tumbuh di Indonesia. Kencana et al., (2012) menyatakan bahwa salah satu jenis bambu yang dapat tumbuh baik di Bali khususnya di daerah Pupuan, Kabupaten Tabanan adalah bambu Tabah (Gigantochloa nigrociliata BUSE-KURZ). Menurut klasifikasi botani, bambu Tabah termasuk kingdom Plantae, divisi Magnoliophyta, kelas Monocotyledoneae, ordo Graminales, famili Gramineae, subfamili Bambusoideae genus Gigantochloa, spesies 
Gigantochloa nigrociliata BUSE-KURZ (Kencana et al., (2012). Bambu Tabah merupakan varietas asli yang berasal dari Pupuan-Tabanan dan banyak dibudidayakan di desa Payangan Gianyar (Padmiswari et al. 2015).Teh merupakan minuman yang paling banyak dikonsumsi setelah air (Damayanthi, 2008). Aroma teh yang harum dan warnanya yang coklat serta rasanya yang khas membuat minuman ini banyak dikonsumsi. Teh biasanya terbuat dari pucuk daun muda pada tanaman teh (Camelia sinensis L. Kuntze), namun teh dapat terbuat dari daun lain seperti daun sirsak, daun alpukat, daun kersen, daun pacar air dan daun bambu. Teh yang dibuat selain dari daun teh (Camellia sinensis) disebut dengan teh herbal (Winarsi, 2005). Teh herbal pada dasarnya campuran herbal yang terbuat dari daun, biji dan akar berbagai tanaman. teh herbal tidak seperti teh pada umumnya yang menggunakan daun Camellia sinensis, dimana teh herbal tidak mengandung cafein (Ravikumar, 2014). Pada bagian daun bambu menurut (Zhang et al. 2005) menyatakan bahwa daun bambu mengandung komponen bioaktif cukup tinggi, antara lain mengandung flavonoid, lakton, dan asam fenolat yaitu senyawa-senyawa yang berperan sebagai antioksidan dan anti mikrobial. Ketiga senyawa ini sangat berguna menunjang kesehatan.

Steam blanching atau pengukusan merupakan media yang diharapkan dapat untuk mengurangi kontaminasi mikroorganisme dan melunakkan jaringan tanaman. Sehingga dalam penelitian ini diharapkan perlakuan steam blanching mampu memberikan manfaat yang maksimal dalam pemanfaatan daun bambu Tabah sebagai olahan teh. Perlakuan blanching yang tepat dapat memiliki banyak manfaat antara lain dapat menghindari perubahan yang tidak diinginkan, mengurangi kandungan mikroba, dapat mempertahankan warna, memperlunak jaringan, membantu pengeluaran gasgas seluler pada jaringan sehingga mencegah terjadinya korosi dan memperbaiki tekstur pada bahan pangan yang dikeringkan (Winarno F.G., 2002).

Pembuatan teh herbal daun bambu Tabah juga menggunakan metode pengeringan. Metode pengeringan yang digunakan dalam penelitian ini yaitu pengeringan secara non konvensional yaitu dengan oven. Pengeringan oven memiliki keunggulan yaitu suhu pengeringan yang digunakan mudah diatur (Hartuti, 1997). Metode pengeringan bertujuan untuk mengeluarkan atau menghilangkan sebagian air dari suatu bahan dengan cara menguapkan air tersebut dengan menggunakan energi panas. Pengurangan kadar air dilakukan untuk menghambat pertumbuhan mikroorganisme dan kegiatan ensim yang dapat menyebabkan pembusukan akan terhenti, sehingga bahan yang dikeringkan dapat bertahan lebih lama.
Tujuan dari penelitian ini ialah untuk mengetahui pengaruh lama steam blanching dan suhu pengeringan terhadap karakteristik kimia serta sensori teh daun bambu Tabah yang dihasilkan. Serta mengetahui kombinasi yang terbaik terhadap karakteristik kimia serta sensori teh daun bambu Tabah yang dihasilkan

\section{METODE PENELITIAN}

\section{Tempat dan Waktu Penelitian}

Penelitian ini dilakukan di Laboratorium Analisis Pangan, Program Studi Ilmu dan Teknologi Pangan, Fakultas Teknologi Pertanian, Universitas Udayana, dan Laborato-rium Teknik Pascapanen, Program Studi Teknik Pertanian, Fakultas Teknologi Pertanian, Universitas Udayana mulai bulan Mei sampai dengan bulan Juli 2019.

\section{Alat dan Bahan}

Bahan-bahan yang digunakan dalam penelitian ini adalah daun bambu Tabah, aquadest, air suling, amilum, indikator PP (phenolphtalin), $\mathrm{NaOH}$, methanol $85 \%$, sodium carbonate, asam galat, folin ciocalteau, dan $\mathrm{Na} 2 \mathrm{CO} 3$.

Alat-alat yang digunakan dalam penelitian ini adalah kompor listrik, panci, saringan kukusan, sensor suhu termokopel, stopwatch, teko air, gunting, desikator, cawan, oven, blender, timbangan analitik, pinset, $\mathrm{pH}$ meter, labu erlenmeyer, corong, gelas ukur, gelas beker, buret, labu ukur, ayakan 40 mesh, pipet tetes, kuvet, pipet volume, boult, $5 \mathrm{ml}$ bola hisap, tabung reaksi, spatula, vortex shaker, corong plastik, keranjang plastik, kertas saring, spectrophotometer UV-Vis, bufet, tabung centrifuge, kantong teh dan pipet mikro

\section{Rancangan Penelitian}

Rancangan percobaan yang digunakan dalam penelitian ini adalah Rancangan Acak Lengkap (RAL) dengan dua faktor dengan tiga kali pengulangan. Faktor yang digunakan dalam rancangan penelitian ini adalah waktu steam blanching dan suhu pengeringan yang terdiri dari sembilan kombinasi perlakuan. Faktor pertama adalah waktu steam blanching (W) yang terdiri dari 3 taraf perlakuan yaitu $\mathrm{W} 1=10$ menit, $\mathrm{W} 2=15$ menit, dan $\mathrm{W} 3=20$ menit. Sedangkan suhu steam blanching (P) yang dipergunakan yaitu $\mathrm{P}= \pm 60^{\circ} \mathrm{C}$. Faktor kedua adalah suhu pengeringan (S) yang terdiri dari 3 taraf perlakuan yaitu $\mathrm{S} 1=50^{\circ} \mathrm{C}, \mathrm{S} 2=60^{\circ} \mathrm{C}$, dan $\mathrm{S} 3=70^{\circ} \mathrm{C}$. Sedangkan waktu pengeringan (T) yang dipergunakan yaitu $\mathrm{T} 1=2 \mathrm{jam}$. Dari dua jenis faktor tersebut akan diperoleh 9 kombinasi perlakuan dengan 3 kali pengulangan, sehingga didapatkan 27 (dua puluh tujuh) satuan percobaan. 


\section{Pelaksanaan Penelitian \\ Persiapan Bahan}

Daun bambu Tabah dipanen di Desa Padangan, Kecamatan Pupuan, Kabupaten Tabanan. Pohon bambu yang dipanen daunnya adalah pohon bambu yang sudah berumur \pm 2 tahun, dengan ciri-ciri tidak terdapatnya pelepah yang yang menempel pada ruasruas bambu dan warna pada batang bambu sudah berwarna hijau kegelapan. Selanjutnya untuk mendapatkan bagian daun dari bambu Tabah dilakukan pemotongan ranting dari batang bambu Tabah terlebih dahulu dengan menggunakan sabit lalu setelah ranting terpotong dilakukan pemotongan daun dari ranting dengan menggunakan gunting, daun yang dipotong dari ranting adalah daun pertama, daun kedua, dan daun ketiga dari ujung ranting. Daun bambu Tabah yang telah dipotong kemudian dimasukan kedalam plastik besar dan diletakan ditempat cold storage yang dimiliki oleh kelompok tani Bambu Alam Sejahtera. Daun bambu yang sudah dipotong dari ranting kemudian dipindahkan ke Laboratorium Sumber Daya Alam Teknik Pertanian Universitas Udayana. Daun bambu kemudian dicuci menggunakan air untuk menghilangkan kotoran yang menempel dalam daun bambu kemudian daun bambu yang sudah dicuci ditiriskan dalam keranjang plastik sampai daun tidak basah lagi. Daun bambu yang sudah kering kemudian ditimbang untuk masingmasing perlakuan sebanyak 300 gram dan selanjutnya dilakukan proses steam blanching menggunakan kompor listrik dan panci.

\section{Proses Pembuatan Teh Herbal Daun Bambu Tabah}

Proses pembuatan teh daun bambu Tabah diawali dengan menimbang daun bambu yang sudah bersih yang akan digunakan masing-masing sebanyak 300 gram pada masing-masing sampel. Kemudian persiapan alat diawali dengan memanaskan air 5000 $\mathrm{ml}$ didalam steamer (panci pengukus) menggunakan kompor listrik hingga menghasilkan suhu didalam panci mencapai $\pm 60 \mathrm{oC}$. Pengukuran suhu dilakukan dengan menggunakan termokopel dimana sensor termokopel dimasukkan kedalam panci yang telah dilubangi tutupnya. Selanjutnya proses steam blanching atau cara pengukusan ini dilakukan dengan cara pemberian suhu dan waktu dengan uap air. Proses pengukusan dilakukan dalam panci tertutup dan menggunakan air yang sedikit, hal ini bertujuan untuk meminimalisasi kehilangan vitamin (Gaman \& Sherrington, 1994). Proses steam blanching yang digunakan mengikuti cara yang dilakukan oleh Nurhuda et al. (2013) yang telah dimodifikasi. Daun bambu Tabah dengan massa $300 \mathrm{~g}$ dipanaskan didalam steamer secara bergantian dengan 3 interval lama pemanasan yakni 10 menit, 15 menit, dan 20 menit per masing-masing berat bahan. Setiap melakukan proses steam blanching, air didalam panci diganti. Masing-masing perlakuan diulang sebanyak 3 kali ulangan. Setelah proses steam blanching daun bambu dipotong dengan ukuran $\pm 5 \mathrm{~cm}$ dengan menggunakan gunting kemudian daun bambu yang sudah dipotong ditimbang dengan berat 80 gram pada masing-masing sampel dan dilanjutkan dengan proses pengeringan. Sebelum melakukan proses pengeringan suhu pada oven disetting terlebih dahulu suhu yang digunakan yakni tiga interval suhu yakni $50^{\circ} \mathrm{C}, 60^{\circ} \mathrm{C}$, dan suhu $70^{\circ} \mathrm{C}$. Kemudian setelah mencapai suhu yang sudah ditentukan daun bambu Tabah yang sudah dipotong dimasukan ke dalam oven dengan lama pengeringan yaitu 2 jam.

\section{Parameter Penelitian}

Setiap sampel daun bambu Tabah kering dianalisis kadar air, $\mathrm{pH}$, total asam, total fenol, dan organoleptik (warna, aroma, rasa) serta hedonik yang dilakukan setelah penyeduhan teh herbal daun bambu Tabah. Proses penyeduhan teh dilakukuan dengan cara mengambil daun bambu yang sudah di kemas ke dalam kantong teh sebanyak 2,5 g lalu diseduh dengan air panas $220 \mathrm{ml}$, setelah itu dilakukan uji organoleptik dari segi warna, aroma, dan rasa teh herbal daun bambu Tabah.

\section{HASIL DAN PEMBAHASAN}

\section{Kadar Air}

Berdasarkan hasil penelitian data kadar air menunjukan bahwa semakin tinggi suhu pengeringan maka kadar air yang terkandung dalam teh daun bambu Tabah yang dihasilkan semakin rendah. Adapun nilai rata-rata kadar air teh daun bambu Tabah yang dihasilkan dari berbagai kombinasi perlakuan dapat dilihat pada Gambar 1.

Berdasarkan hasil analisis sidik ragam menujukan bahwa perlakuan waktu steam blanching, perlakuan suhu pengeringan dan kombinasi kedua perlakuan berpengaruh sangat nyata $(\mathrm{P}<0,01)$ terhadap kadar air teh daun bambu Tabah yang dihasilkan. Hasil uji BNT (Beda Nyata Terkecil) menunjukan bahwa perlakuan waktu steam blanching 10 menit dengan suhu pengeringan $50^{\circ} \mathrm{C}\left(\mathrm{W}_{1} \mathrm{~S}_{1}\right)$ berbeda nyata dengan perlakuan waktu steam blanching 10 menit dengan suhu pengeringan $60^{\circ} \mathrm{C}\left(\mathrm{W}_{1} \mathrm{~S}_{2}\right)$ berbeda nyata dengan perlakuan waktu steam blanching 10 menit dengan suhu pengeringan $70^{\circ} \mathrm{C}\left(\mathrm{W}_{1} \mathrm{~S}_{3}\right)$ berbeda nyata dengan perlakuan waktu steam blanching 15 menit dengan suhu pengeringan $50^{\circ} \mathrm{C}\left(\mathrm{W}_{2} \mathrm{~S}_{1}\right)$ berbeda nyata dengan perlakuan waktu steam blanching 15 menit dengan suhu pengeringan $60^{\circ} \mathrm{C} \quad\left(\mathrm{W}_{2} \mathrm{~S}_{2}\right)$, waktu steam blanching 20 menit dengan suhu pengeringan $70^{\circ} \mathrm{C}$ $\left(\mathrm{W}_{3} \mathrm{~S}_{3}\right)$ berbeda nyata dengan waktu steam blanching 15 menit dengan suhu pengeringan $70^{\circ} \mathrm{C}\left(\mathrm{W}_{2} \mathrm{~S}_{3}\right)$ berbeda nyata dengan waktu steam blanching 20 
menit dengan suhu pengeringan $50^{\circ} \mathrm{C}\left(\mathrm{W}_{3} \mathrm{~S}_{3}\right)$ dan berbeda nyata dengan waktu steam blanching 20 menit dengan suhu pengeringan $60^{\circ} \mathrm{C} \quad\left(\mathrm{W}_{3} \mathrm{~S}_{2}\right)$. Gambar 1 menunjukan bahwa kadar air teh daun bambu Tabah yang dihasilkan berkisar antara $6,17 \%$ sampai $8,83 \%$.

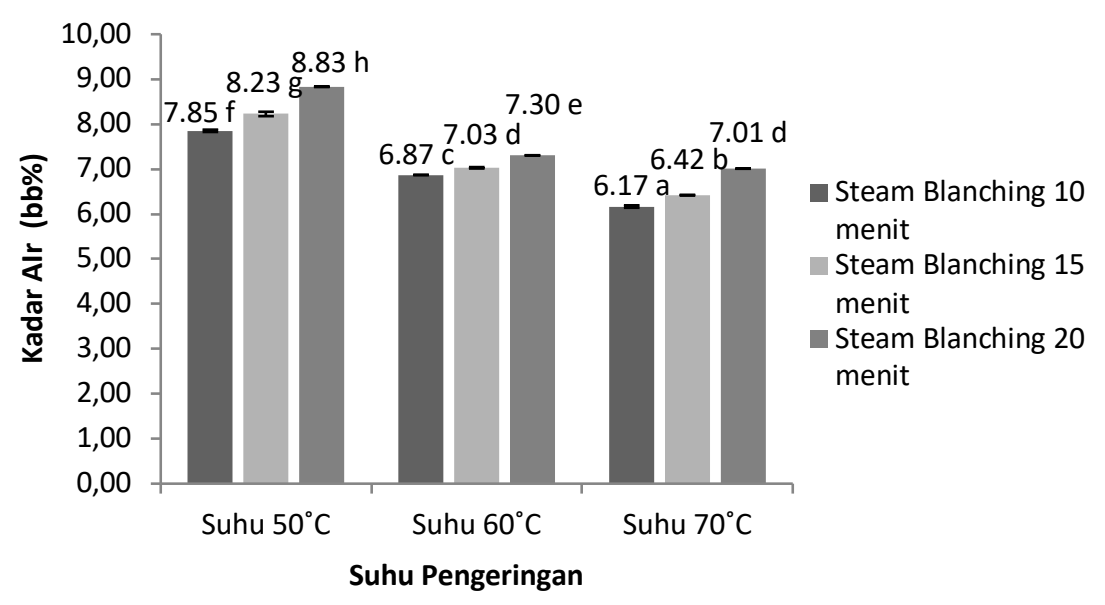

Gambar 1. Nilai rata-rata kadar air teh daun bambu Tabah dari berbagai perlakuan waktu steam blanching dan suhu pengeringan. Keterangan: Huruf yang sama dibelakang nilai rata-rata yang sama menunjukan nilai yang tidak berbeda nyata bedasarkan uji BNT $(\mathrm{P}>0,05)$.

Nilai kadar air terendah yaitu $6,17 \%$ terdapat pada perlakuan waktu steam blanching 10 menit dengan suhu pengeringan $70^{\circ} \mathrm{C}\left(\mathrm{W}_{1} \mathrm{~S}_{3}\right)$. Nilai kadar air tertinggi yaitu $8,83 \%$ terdapat pada perlakuan waktu steam blanching 20 menit dengan suhu pengeringan $50^{\circ} \mathrm{C}\left(\mathrm{W}_{3} \mathrm{~S}_{1}\right)$. Semakin lama waktu steam blanching mengakibatkan daun menjadi lebih basah sehingga memperlihatkan kadar air daun bambu Tabah yang lebih tinggi. Daun bambu basah akibat suhu steam blanching terus meningkat dikarenakan waktu steam blanching yang diberikan terlalu lama hal tersebut berpengaruh terhadap pembengkakan pori didalam jaringan daun tersebut.

Pembengkakan pori yang terjadi didalam daun mengakibatkan berdisfusinya air kedalam jaringan daun selama proses steam blanching sehingga mempengaruhi peningkatan fase keterikatan air. Ketika dikeringkan, produk yang mendisfusi air lebih banyak akan menunjukan kadar air yang lebih tinggi. Didalam jaringan fase keterikatan air dapat berupa beberapa fase. Menurut Sudjatha (2001) jenis fase keterikatan air didalam produk dapat dibagi menjadi tiga yaitu air yang terikat secara bebas, secara fisik dan terikat secara kimia. Adanya perbedaan kadar air ini erat kaitannya dengan perbedaan penyerapan air selama steam blanching seperti yang dilaporkan oleh Dewanto et al, (2002) bahwa pada blanching terjadi pelunakan jaringan akibat adanya penyerapan air yang menyebabkan terjadinya peningkatan massa. Nilai rata-rata kadar air kombinasi keseluruhan yaitu $7.30 \%$, pengeringan dalam oven jelas memperlihatkan bahwa jumlah kehilangan air meningkat seiring dengan meningkatnya suhu pengeringan (Asri, 2009).

Hal ini menunjukkan bahwa semakin tinggi suhu pengeringan maka terjadi penurunan kadar air. Menurut Fitriani (2008), hal ini terjadi karena meningkatnya kemampuan suatu bahan untuk melepaskan air dari permukaannya seiring dengan meningkatnya suhu udara pengering. Menurut Winarno (1997), semakin tinggi suhu pengeringan maka semakin cepat terjadi penguapan, sehingga kandungan air dalam bahan semakin rendah. Standar kadar air untuk produk teh yang ditetapkan oleh Standar Nasional Indonesia (SNI 01-3945-2016) mengenai standar mutu teh kering yaitu kadar air maksimal adalah 8\% (b/b). Dari kombinasi kedua perlakuan hasil rata-rata kadar air yang diperoleh pada setiap perlakuan menunjukkan bahwa perlakuan yang tidak memenuhi standar kadar air teh menurut Standar Nasional Indonesia (SNI) yaitu perlakuan waktu steam blanching 15 menit dengan suhu pengeringan $50^{\circ} \mathrm{C}\left(\mathrm{W}_{2} \mathrm{~S}_{1}\right)$ dengan nilai kadar air yaitu $8,23 \%$ dan perlakuan waktu steam blanching 20 menit dengan suhu pengeringan $50^{\circ} \mathrm{C}\left(\mathrm{W}_{3} \mathrm{~S}_{1}\right)$ dengan nilai kadar air yaitu $8,83 \%$.

\section{Nilai pH}

Nilai pH didefinisikan sebagai logaritma aktivitas ion hidrogen $\left(\mathrm{H}^{+}\right)$yang terlarut. $\mathrm{pH}$ atau derajat keasaman digunakan untuk menyatakan tingkat keasaman atau kebasaan yang dimiliki oleh suatu larutan (Winarno, 1997). Adapun nilai rata-rata $\mathrm{pH}$ teh daun bambu Tabah yang dihasilkan dari berbagai kombinasi perlakuan dapat dilihat pada Gambar 2. 


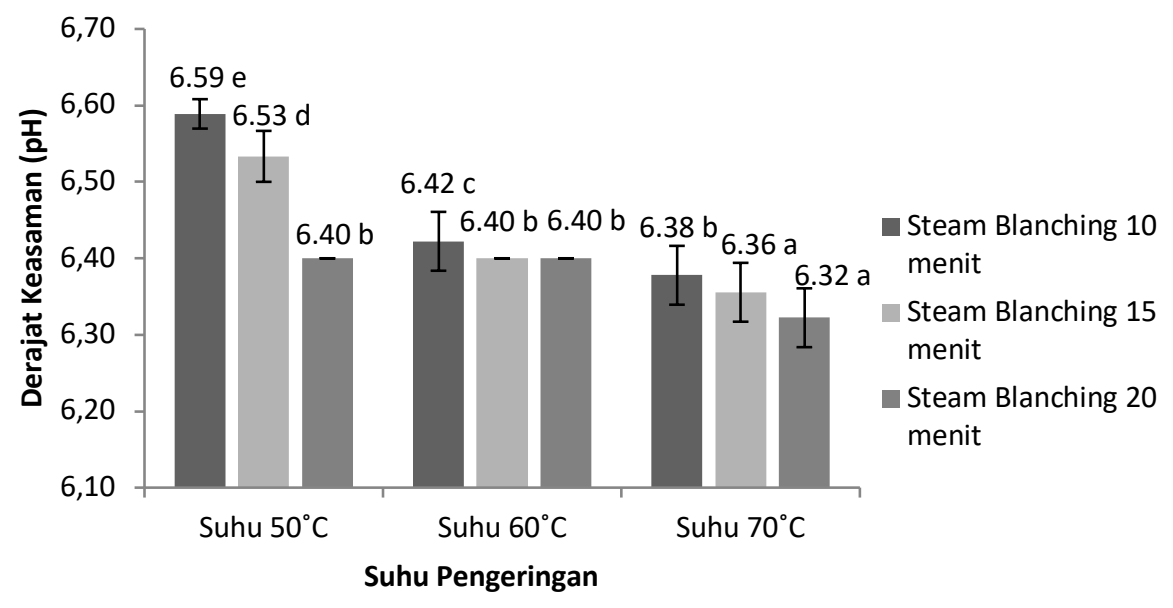

Gambar 2. Nilai rata-rata $\mathrm{pH}$ teh daun bambu Tabah dari berbagai perlakuan waktu steam blanching dan suhu pengeringan. Keterangan : Huruf yang sama dibelakang nilai rata-rata yang sama menunjukan nilai yang tidak berbeda nyata berdasarkan uji BNT $(\mathrm{P}>0,05)$.

Berdasarkan hasil sidik ragam menunjukan bahwa perlakuan waktu steam blanching, perlakuan suhu pengeringan dan kombinasi kedua perlakuan berpengaruh sangat nyata $(\mathrm{P}<0,01)$ terhadap nilai $\mathrm{pH}$ teh daun bambu Tabah yang dihasilkan. Hasil uji BNT (Beda Nyata Terkecil) menunjukan bahwa perlakuan waktu steam blanching 10 menit dengan suhu pengeringan $50^{\circ} \mathrm{C}\left(\mathrm{W}_{1} \mathrm{~S}_{1}\right)$ berbeda nyata dengan perlakuan waktu steam blanching 10 menit dengan suhu pengeringan $60^{\circ} \mathrm{C}\left(\mathrm{W}_{1} \mathrm{~S}_{2}\right)$ berbeda nyata dengan perlakuan waktu steam blanching 10 menit dengan suhu pengeringan $70^{\circ} \mathrm{C} \quad\left(\mathrm{W}_{1} \mathrm{~S}_{3}\right)$, waktu steam blanching 15 menit dengan suhu pengeringan $60^{\circ} \mathrm{C}$ $\left(\mathrm{W}_{2} \mathrm{~S}_{2}\right)$ waktu steam blanching 20 menit dengan suhu pengeringan $50^{\circ} \mathrm{C}\left(\mathrm{W}_{3} \mathrm{~S}_{1}\right)$, waktu steam blanching 20 menit dengan suhu pengeringan $60^{\circ} \mathrm{C}\left(\mathrm{W}_{3} \mathrm{~S}_{2}\right)$ berbeda nyata dengan perlakuan waktu steam blanching 15 menit dengan suhu pengeringan $50^{\circ} \mathrm{C}\left(\mathrm{W}_{2} \mathrm{~S}_{1}\right)$ dan berbeda nyata dengan perlakuan waktu steam blanching 15 menit dengan suhu pengeringan $70^{\circ} \mathrm{C}$ $\left(\mathrm{W}_{2} \mathrm{~S}_{3}\right)$, waktu steam blanching 20 menit dengan suhu pengeringan $70^{\circ} \mathrm{C}\left(\mathrm{W}_{3} \mathrm{~S}_{3}\right)$. Gambar 2 menunjukan bahwa nilai $\mathrm{pH}$ teh daun bambu Tabah yang dihasilkan berkisar antara 6.32 sampai 6,59.

Nilai pH terendah yaitu 6,32 terdapat pada perlakuan waktu steam blanching 20 menit dengan suhu pengeringan $70^{\circ} \mathrm{C}\left(\mathrm{W}_{3} \mathrm{~S}_{3}\right)$. Nilai $\mathrm{pH}$ tertinggi yaitu 6.59 terdapat pada perlakuan waktu steam blanching 10 menit dengan suhu pengeringan $50^{\circ} \mathrm{C}\left(\mathrm{W}_{1} \mathrm{~S}_{1}\right)$. Nilai rata-rata $\mathrm{pH}$ kombinasi keseluruhan yaitu 6.42. Dari kedua kombinasi perlakuan steam blanching dan suhu pengeringan mampu menurukan nilai $\mathrm{pH}$ dari daun bambu Tabah. Dimana $\mathrm{pH}$ awal dari daun bambu Tabah tanpa perlakuan yaitu 6,73 setelah kombinasi perlakuan turun hingga $\mathrm{pH}$ paling rendah yaitu 6,32.

Penurunan nilai $\mathrm{pH}$ kemungkinan disebabkan oleh adanya proses blanching. Perlakuan steam blanching tersebut diduga akan menyebabkan terjadinya pemecahan senyawa seperti lemak menjadi asamasam lemak dan protein menjadi asam-asam amino sehingga akan menyebabkan keasaman ekstrak daun bambu Tabah meningkat dan nilai $\mathrm{pH}$ menjadi rendah. Hal ini didukung oleh Fennema (1996) bahwa pada proses blanching pada sayuran hijau akan membentuk asam-asam yang lebih besar sebagai hasil dari pembentukan asam-asam baru. Penurunan nilai $\mathrm{pH}$ juga disebabkan oleh suhu pengeringan. Semakin rendah nilai $\mathrm{pH}$ dikarenakan semakin tinggi suhu dan lama proses pengeringan yang akan mempercepat penguapan dan menyebabkan kandungan dalam ekstrak berkurang sehingga mempengaruhi kadar $\mathrm{pH}$ (Hamidah et al., 2014). Menurut Tranggono dan Sutradi (1989) nilai pH ditentukan oleh banyak sedikitnya asam yang ada dalam bahan. Jika total asam besar, maka nilai $\mathrm{pH}$ akan rendah.

\section{Kadar Total Asam}

Peningkatan total asam pada media karena terbentuknya senyawa-senyawa asam organik terutama asam asetat. Senyawa-senyawa asam tersebut terbentuk karena adanya aktivitas dari bakteri yang dapat mengubah senyawa glukosa menjadi senyawa asam organik (Jodoamidjojo et al, 1992). Adapun nilai rata-rata kadar total asam teh daun bambu Tabah yang dihasilkan dari berbagai kombinasi perlakuan dapat dilihat pada Gambar 3 . 


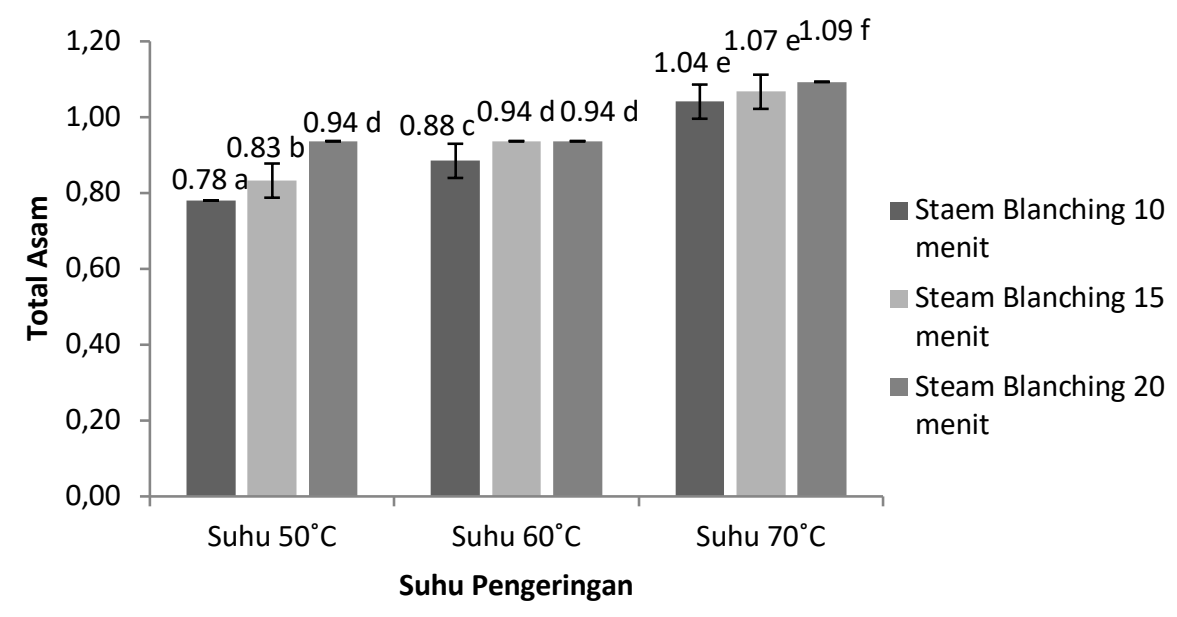

Gambar 3. Nilai rata-rata total asam teh daun bambu Tabah dari berbagai perlakuan waktu steam blanching dan suhu pengeringan. Keterangan : Huruf yang sama dibelakang nilai rata-rata yang sama menunjukan nilai yang tidak berbeda nyata berdasarkan uji BNT $(\mathrm{P}>0,05)$.

Berdasarkan hasil analisis sidik ragam menujukan bahwa perlakuan waktu steam blanching dan perlakuan suhu pengeringan berpengaruh sangat nyata $(\mathrm{P}<0,01)$. Sedangkan untuk kombinasi kedua perlakuan berpengaruh nyata $(\mathrm{P}<0,05)$ terhadap total asam teh daun bambu Tabah yang dihasilkan. Hasil uji BNT (Beda Nyata Terkecil) menunjukan bahwa perlakuan waktu steam blanching 10 menit dengan suhu pengeringan $50^{\circ} \mathrm{C}\left(\mathrm{W}_{1} \mathrm{~S}_{1}\right)$ berbeda nyata dengan perlakuan waktu steam blanching 10 menit dengan suhu pengeringan $60^{\circ} \mathrm{C}\left(\mathrm{W}_{1} \mathrm{~S}_{2}\right)$ berbeda nyata dengan perlakuan waktu steam blanching 10 menit dengan suhu pengeringan $70^{\circ} \mathrm{C} \quad\left(\mathrm{W}_{1} \mathrm{~S}_{3}\right)$, waktu steam blanching 15 menit dengan suhu pengeringan $70^{\circ} \mathrm{C}$ $\left(\mathrm{W}_{1} \mathrm{~S}_{3}\right)$ berbeda nyata dengan perlakuan waktu steam blanching 15 menit dengan suhu pengeringan $50^{\circ} \mathrm{C}$ $\left(\mathrm{W}_{2} \mathrm{~S}_{1}\right)$ berbeda nyata dengan perlakuan waktu steam blanching 15 menit dengan suhu pengeringan $60^{\circ} \mathrm{C}$ $\left(\mathrm{W}_{2} \mathrm{~S}_{2}\right)$, steam blanching 20 menit dengan suhu pengeringan $50^{\circ} \mathrm{C}\left(\mathrm{W}_{3} \mathrm{~S}_{1}\right)$ steam blanching 20 menit dengan suhu pengeringan $60^{\circ} \mathrm{C}\left(\mathrm{W}_{3} \mathrm{~S}_{2}\right)$ dan berbeda nyata dengan perlakuan waktu steam blanching 20 menit dengan suhu pengeringan $70^{\circ} \mathrm{C} \quad\left(\mathrm{W}_{3} \mathrm{~S}_{3}\right)$. Gambar 3 menunjukan bahwa total asam teh daun bambu Tabah yang dihasilkan berkisar antara $0.78 \%$ sampai $1.09 \%$.

Nilai total asam terendah yaitu $0.78 \%$ terdapat pada perlakuan waktu steam blanching 10 menit dengan suhu pengeringan $50^{\circ} \mathrm{C}\left(\mathrm{W}_{1} \mathrm{~S}_{1}\right)$. Nilai total asam tertinggi yaitu $1.09 \%$ terdapat pada perlakuan waktu steam blanching 20 menit dengan suhu pengeringan $70^{\circ} \mathrm{C} \%\left(\mathrm{~W}_{3} \mathrm{~S}_{3}\right)$. Fennema (1996) bahwa pada proses blanching pada sayuran hijau akan membentuk asamasam yang lebih besar sebagai hasil dari pembentukan asam-asam baru. Kenaikan asam ini akibat dari hidrolisis lemak pembentukan $\mathrm{CO}_{2}$ hasil browning. Nilai rata-rata total asam kombinasi keseluruhan yaitu $0.95 \%$. Semakin tinggi total asam, $\mathrm{pH}$ semakin turun (Wood dan Lass 1985).

\section{Kadar Total Fenol}

Fenol merupakan senyawa yang memiliki fungsi sebagai antioksidan yang memiliki peran sebagai pemberi cita rasa atau flavour pada bahan pangan serta memperpanjang masa simpan karena senyawa fenol memiliki efek antibakteri dan antimikroba (Sutriyono, 2016). Adapun nilai rata-rata total fenol teh daun bambu Tabah yang dihasilkan dari berbagai kombinasi perlakuan dapat dilihat pada Gambar 4. Berdasarkan hasil analisis sidik ragam menujukan bahwa perlakuan waktu steam blanching, perlakuan suhu pengeringan dan kombinasi kedua perlakuan berpengaruh sangat nyata $(\mathrm{P}<0,01)$ terhadap total fenol teh daun bambu Tabah yang dihasilkan. Hasil uji BNT (Beda Nyata Terkecil) menunjukan bahwa perlakuan waktu steam blanching 10 menit dengan suhu pengeringan $50^{\circ} \mathrm{C}\left(\mathrm{W}_{1} \mathrm{~S}_{1}\right)$ berbeda nyata dengan perlakuan waktu steam blanching 10 menit dengan suhu pengeringan $60^{\circ} \mathrm{C} \quad\left(\mathrm{W}_{1} \mathrm{~S}_{2}\right)$, waktu steam blanching 15 menit dengan suhu pengeringan $50^{\circ} \mathrm{C}$ $\left(\mathrm{W}_{2} \mathrm{~S}_{1}\right)$, waktu steam blanching 20 menit dengan suhu pengeringan $50^{\circ} \mathrm{C}\left(\mathrm{W}_{3} \mathrm{~S}_{1}\right)$ berbeda nyata dengan perlakuan waktu steam blanching 10 menit dengan suhu pengeringan $70^{\circ} \mathrm{C} \quad\left(\mathrm{W}_{1} \mathrm{~S}_{3}\right)$, waktu steam blanching 15 menit dengan suhu pengeringan $60^{\circ} \mathrm{C}$ $\left(\mathrm{W}_{2} \mathrm{~S}_{2}\right)$ berbeda nyata dengan perlakuan waktu steam blanching 15 menit dengan suhu pengeringan $70^{\circ} \mathrm{C}$ $\left(\mathrm{W}_{2} \mathrm{~S}_{3}\right)$ berbeda nyata dengan perlakuan waktu steam blanching 20 menit dengan suhu pengeringan $60^{\circ} \mathrm{C}$ $\left(\mathrm{W}_{3} \mathrm{~S}_{2}\right)$ dan berbeda nyata dengan perlakuan waktu steam blanching 20 menit dengan suhu pengeringan $70^{\circ} \mathrm{C}\left(\mathrm{W}_{3} \mathrm{~S}_{3}\right)$.. Gambar 4 menunjukan bahwa total fenol teh daun bambu Tabah yang dihasilkan berkisar antara $54,24 \mathrm{mg} / 100 \mathrm{~g}$ sampai $55,58 \mathrm{mg} / 100 \mathrm{~g}$. 


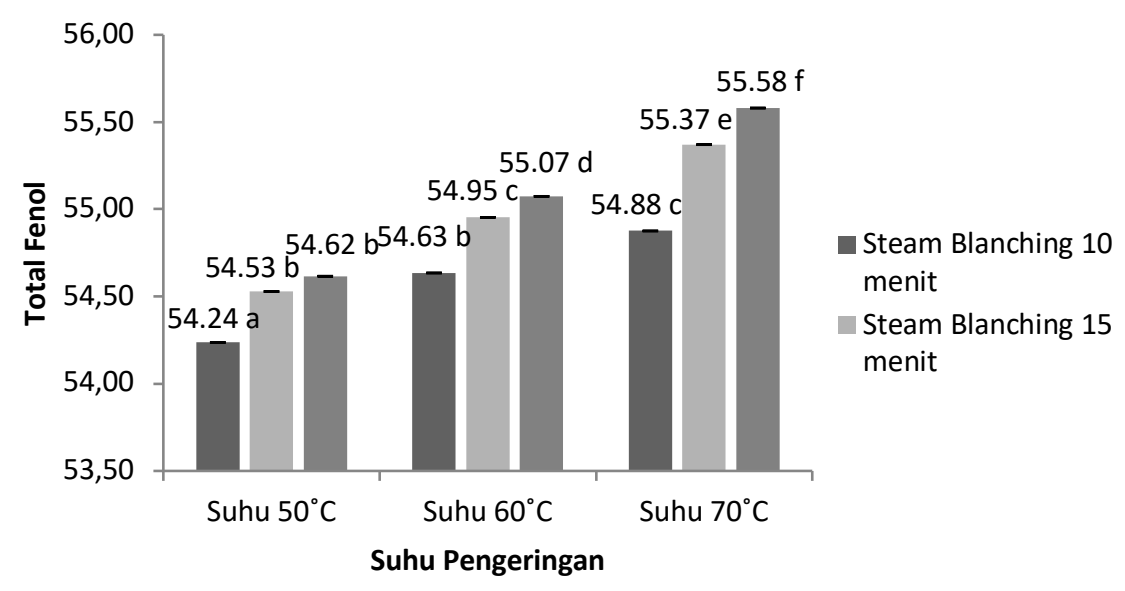

Gambar 4. Nilai rata-rata total fenol teh daun bambu Tabah dari berbagai perlakuan waktu steam blanching dan suhu pengeringan. Keterangan : Huruf yang sama dibelakang nilai rata-rata yang sama menunjukan nilai yang tidak berbeda nyata berdasarkan uji BNT $(\mathrm{P}>0,05)$.

Nilai total fenol terendah yaitu $54,24 \mathrm{mg} / 100 \mathrm{~g}$ terdapat pada perlakuan waktu steam blanching 10 menit dengan suhu pengeringan $50^{\circ} \mathrm{C}\left(\mathrm{W}_{1} \mathrm{~S}_{1}\right)$. Nilai total asam tertinggi yaitu $55,58 \mathrm{mg} / 100 \mathrm{~g}$ terdapat pada perlakuan waktu steam blanching 20 menit dengan suhu pengeringan $70^{\circ} \mathrm{C}\left(\mathrm{W}_{3} \mathrm{~S}_{3}\right)$. Nilai rata-rata total fenol kombinasi keseluruhan yaitu 54,87 $\mathrm{mg} / 100 \mathrm{~g}$. Perlakuan blanching terhadap daun bambu Tabah memberikan korelasi yang positif terhadap peningkatan aktivitas antioksidan, kadar total fenol, flavonoid dan kadar tenin terkondensasi (Pujimulyani et al., 2010). Peningkatan kadar total fenol diduga akibat terjadi degradasi tannin menjadi senyawa fenol yang lebih sederhana (Pujimulyani et al., 2010). Meningkatnya kadar fenol akibat proses blanching juga terjadi pada penelitian (Roy et al., 2009) terjadi peningkatan kadar fenol pada brokoli segar 135,66 mgEAG/100g menjadi 144,33 mgEAG/100g setelah mengalami blanching selama 5 menit. Pengeringan juga mempengaruhi peningkatan kadar total fenol semakin meningkatnya suhu pengeringan menyebabkan total fenol teh daun bambu Tabah semakin tinggi.

Hal ini terjadi karena panas dapat menyebabkan terjadinya kerusakan terhadap komponen penyusun dinding sel daun yaitu karbohidrat (termasuk serat selulosa) dan protein sebagai komponen tidak terlarut. Kerusakan ini dapat memudahkan keluarnya senyawa polifenol dari dalam daun karena polifenol merupakan senyawa yang memiliki berat molekul rendah, sehingga mudah untuk terinfusi ke dalam pelarut (Chu dan Juneja, 1997). Proses pemanasan saat pengeringan juga berfungsi untuk menginaktivasi enzim polifenol oksidase (Tuminah, 2004). Semakain tinggi suhu pengeringan mengakibatkan peningkatan proses inaktivasi enzim polifenol oksidase, sehingga aktivasi enzim akan semakin rendah dan kerusakan senyawa polifenol semakin sedikit, namun jika suhu pengeringan melampaui suhu $100^{\circ} \mathrm{C}$, maka stabilitas senyawa polifenol akan terganggu sehingga dapat menyebabkan penurunan kandungan senyawa polifenol pada bahan (Susanti, 2008).

\section{Organoleptik}

Untuk evaluasi teh daun bambu Tabah dilakukan dengan uji skoring dan uji hedonik. Uji skoring dilakukan terhadap warna, aroma, rasa dan uji hedonik tehadap penerimaan keseluruhan. Untuk uji organoleptik ini dilakukan oleh 15 panelis yang diambil dari kalangan mahasiswa Universitas Udayana.

\section{Warna Air Seduhan Teh Daun Bambu Tabah}

Berdasarkan hasil sidik ragam menunjukan bahwa perlakuan waktu steam blanching, perlakuan suhu pengeringan dan kombinasi kedua perlakuan berpengaruh sangat nyata $(\mathrm{P}<0,01)$ terhadap warna seduhan teh daun bambu Tabah yang dilakukan dengan uji skoring. Rata-rata hasil uji skoring terhadap warna seduhan teh daun bambu Tabah dapat dilihat pada Gambar 5. 


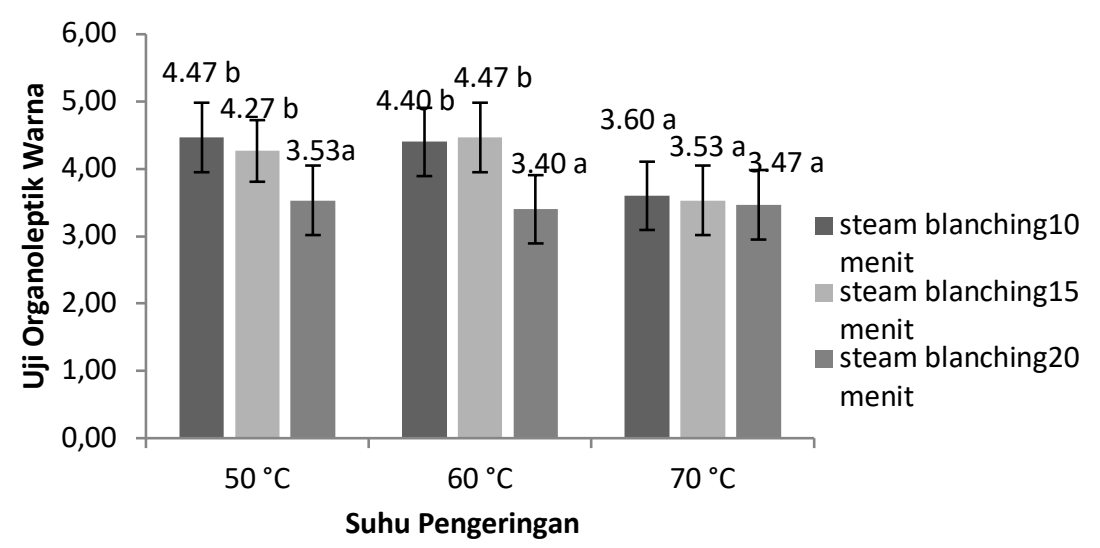

Gambar 5. Nilai rata-rata warna air seduhan teh daun bambu Tabah dari berbagai perlakuan waktu steam blanching dan suhu pengeringan. Keterangan : Huruf yang sama dibelakang nilai rata-rata yang sama menunjukan nilai yang tidak berbeda nyata berdasarkan uji BNT $(\mathrm{P}>0,05)$.

Hasil uji BNT (Beda Nyata Terkecil) menunjukan bahwa perlakuan waktu steam blanching 10 menit dengan suhu pengeringan $50^{\circ} \mathrm{C}\left(\mathrm{W}_{1} \mathrm{~S}_{1}\right)$, waktu steam blanching 10 menit dengan suhu pengeringan $60^{\circ} \mathrm{C}$ $\left(\mathrm{W}_{1} \mathrm{~S}_{2}\right)$, waktu steam blanching 15 menit dengan suhu pengeringan $50^{\circ} \mathrm{C}\left(\mathrm{W}_{2} \mathrm{~S}_{1}\right)$, waktu steam blanching 15 menit dengan suhu pengeringan $60^{\circ} \mathrm{C}\left(\mathrm{W}_{2} \mathrm{~S}_{2}\right)$ berbeda nyata dengan perlakuan waktu steam blanching 10 menit dengan suhu pengeringan $70^{\circ} \mathrm{C}\left(\mathrm{W}_{1} \mathrm{~S}_{3}\right)$, waktu steam blanching 15 menit dengan suhu pengeringan $70^{\circ} \mathrm{C}\left(\mathrm{W}_{2} \mathrm{~S}_{3}\right)$, waktu steam blanching 20 menit dengan suhu pengeringan $50^{\circ} \mathrm{C}\left(\mathrm{W}_{3} \mathrm{~S}_{1}\right)$, waktu steam blanching 20 menit dengan suhu pengeringan $60^{\circ} \mathrm{C}$ $\left(\mathrm{W}_{2} \mathrm{~S}_{2}\right)$ dan waktu steam blanching 20 menit dengan suhu pengeringan $70^{\circ} \mathrm{C}\left(\mathrm{W}_{3} \mathrm{~S}_{3}\right)$.

Hasil rata-rata uji skoring warna seduhan teh daun bambu Tabah dari panelis berkisar antara 3,40 sampai 4,47. Penilaian skor warna terendah dari panelis yaitu 3,40 terdapat pada perlakuan waktu steam blanching 20 menit dengan suhu pengeringan $60^{\circ} \mathrm{C}\left(\mathrm{W}_{3} \mathrm{~S}_{2}\right)$ dengan kriteria warna seduhan adalah kuning cukup cerah. Penilaian skor warna tertinggi dari panelis yaitu 4,47 terdapat pada perlakuan waktu steam blanching 15 menit dengan suhu pengeringan $60^{\circ} \mathrm{C}$ $\left(\mathrm{W}_{2} \mathrm{~S}_{2}\right)$ dengan kriteria warna seduhan adalah kuning kehijauan cerah.

Faktor steam blanching dan pengeringan menyebabkan nilai kecerahan menjadi lebih rendah. Hal ini sesuai dengan hasil statistik anova, bahwa pengaruh faktor steam blanching dan metode pengeringan berpengaruh nyata terhadap skor ratarata kecerahan. Pengaruh steam blanching 20 menit cenderung menurunkan skor kecerahan. Kadar total fenol tertinggi dapat dilihat dari warna seduhan yang dihasilkan. Warna yang lebih pekat menunjukan kadar total fenol yang tinggi dengan aktivitas antioksidan yang tinggi pula (Ramlah, 2017). Total fenol dan dapat memberi warna kuning kecoklatan pada seduhan dan akan berubah menjadi coklat gelap bila terjadi reaksi oksidasi lebih lanjut (Winardi, 2010). Menurut Arpah (1993), senyawa teaflavin memberikan warna merah kekuningan, terang dan berpengaruh terhadap kejernihan seduhan.

\section{Aroma Air Seduhan Teh Daun Bambu Tabah}

Berdasarkan hasil sidik ragam menunjukan bahwa perlakuan waktu steam blanching, perlakuan suhu pengeringan dan kombinasi kedua perlakuan berpengaruh sangat nyata $(\mathrm{P}<0,01)$ terhadap aroma seduhan teh daun bambu Tabah yang dilakukan dengan uji skoring. Rata-rata hasil uji skoring dari panelis terhadap aroma teh daun bambu Tabah dapat dilihat pada Gambar 6.

Hasil uji BNT (Beda Nyata Terkecil) menunjukan bahwa perlakuan waktu steam blanching 10 menit dengan suhu pengeringan $50^{\circ} \mathrm{C}\left(\mathrm{W}_{1} \mathrm{~S}_{1}\right)$, waktu steam blanching 10 menit dengan suhu pengeringan $60^{\circ} \mathrm{C}$ $\left(\mathrm{W}_{1} \mathrm{~S}_{2}\right)$, waktu steam blanching 10 menit dengan suhu pengeringan $70^{\circ} \mathrm{C}\left(\mathrm{W}_{1} \mathrm{~S}_{3}\right)$, waktu steam blanching 15 menit dengan suhu pengeringan $50^{\circ} \mathrm{C}\left(\mathrm{W}_{2} \mathrm{~S}_{1}\right)$, waktu steam blanching 15 menit dengan suhu pengeringan $60^{\circ} \mathrm{C}\left(\mathrm{W}_{2} \mathrm{~S}_{2}\right)$ berbeda nyata dengan perlakuan waktu steam blanching 15 menit dengan suhu pengeringan $70^{\circ} \mathrm{C}\left(\mathrm{W}_{2} \mathrm{~S}_{3}\right)$, waktu steam blanching 20 menit dengan suhu pengeringan $60^{\circ} \mathrm{C}\left(\mathrm{W}_{3} \mathrm{~S}_{2}\right)$, waktu steam blanching 20 menit dengan suhu pengeringan $70^{\circ} \mathrm{C}$ $\left(\mathrm{W}_{3} \mathrm{~S}_{3}\right)$ dan berbeda nyata dengan waktu steam blanching 20 menit dengan suhu pengeringan $50^{\circ} \mathrm{C}$ $\left(\mathrm{W}_{2} \mathrm{~S}_{1}\right)$. Hasil rata-rata uji skoring aroma teh daun bambu Tabah dari panelis berkisar antara 3,80 sampai 4,87 . 


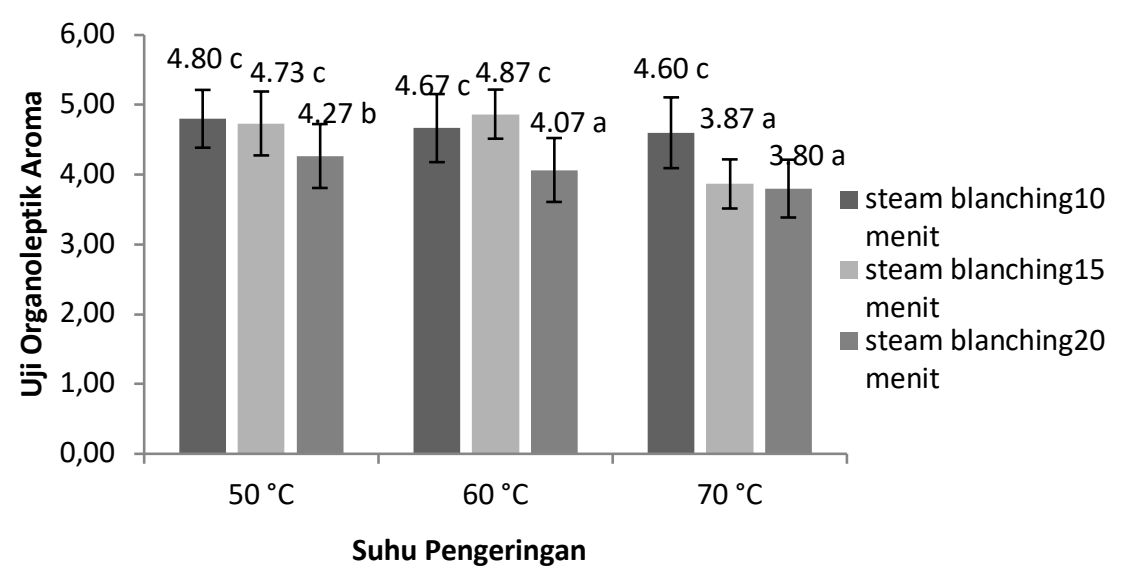

Gambar 6. Nilai rata-rata aroma teh daun bambu Tabah dari berbagai perlakuan waktu steam blanching dan suhu pengeringan. Keterangan : Huruf yang sama dibelakang nilai rata-rata yang sama menunjukan nilai yang tidak berbeda nyata berdasarkan uji BNT $(\mathrm{P}>0,05)$.

Penilaian skor aroma terendah dari panelis yaitu 3,80 terdapat pada perlakuan waktu steam blanching 20 menit dengan suhu pengeringan $70^{\circ} \mathrm{C}\left(\mathrm{W}_{3} \mathrm{~S}_{3}\right)$ dengan kriteria aroma adalah keharuman teh daun bambu Tabah cukup khas. Penilaian skor aroma tertinggi dari panelis yaitu 4,87 terdapat pada perlakuan waktu steam blanching 15 menit dengan suhu pengeringan $60^{\circ} \mathrm{C}\left(\mathrm{W}_{2} \mathrm{~S}_{2}\right)$ dengan kriteria aroma adalah harum teh daun bambu Tabah sangat khas. Semakin tinggi suhu pengeringan yang digunakan maka aroma dari teh daun bambu Tabah semakin menurun. Hal ini disebabkan karena rusaknya senyawa-senyawa aromatik pada proses pengeringan. Menurut Anjarsari (2015), aroma dalam bahan makanan dapat

ditimbulkan oleh beberapa komponen volatil, akan tetapi komponen volatil tersebut dapat hilang selama proses pengolahan terutama panas.

\section{Rasa Air Seduhan Teh Daun Bambu Tabah}

Berdasarkan hasil sidik ragam menunjukan bahwa perlakuan waktu steam blanching, perlakuan suhu pengeringan dan kombinasi kedua perlakuan berpengaruh sangat nyata $(\mathrm{P}<0,01)$ terhadap rasa seduhan teh daun bambu Tabah yang dilakukan dengan uji skoring. Rata-rata hasil uji skoring terhadap rasa teh daun bambu Tabah dapat dilihat pada Gambar 7.

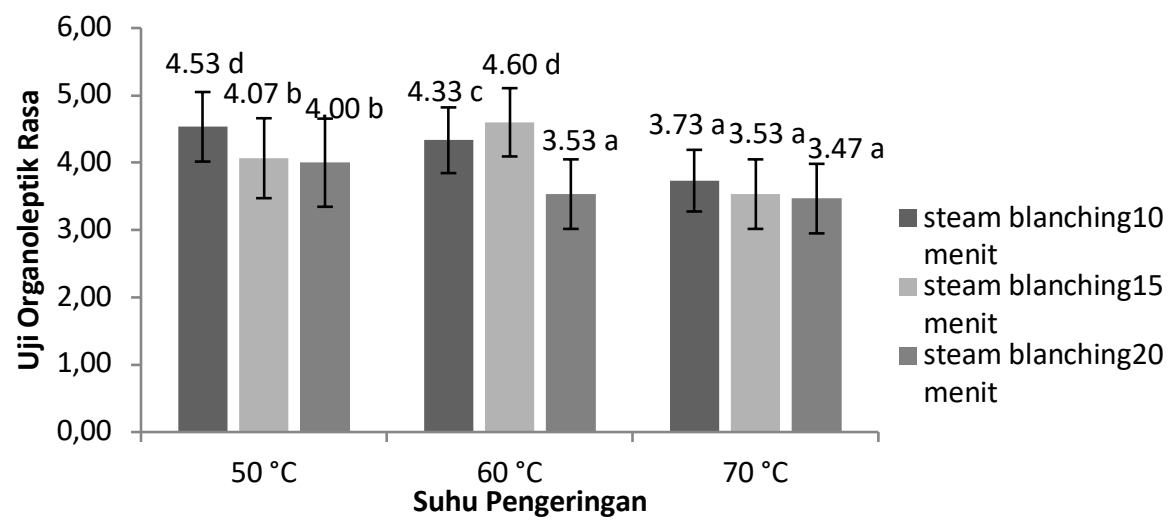

Gambar 7. Nilai rata-rata rasa teh daun bambu Tabah dari berbagai perlakuan waktu steam blanching dan suhu pengeringan. Keterangan : Huruf yang sama dibelakang nilai rata-rata yang sama menunjukan nilai yang tidak berbeda nyata berdasarkan uji BNT $(\mathrm{P}>0,05)$.

Hasil uji BNT (Beda Nyata Terkecil) menunjukan bahwa perlakuan waktu steam blanching 10 menit dengan suhu pengeringan $50^{\circ} \mathrm{C}\left(\mathrm{W}_{1} \mathrm{~S}_{1}\right)$, waktu steam blanching 15 menit dengan suhu pengeringan $60^{\circ} \mathrm{C}$ $\left(\mathrm{W}_{2} \mathrm{~S}_{2}\right)$ berbeda nyata dengan perlakuan waktu steam blanching 10 menit dengan suhu pengeringan $60^{\circ} \mathrm{C}$ $\left(\mathrm{W}_{1} \mathrm{~S}_{2}\right)$ berbeda nyata dengan perlakuan waktu steam blanching 10 menit dengan suhu pengeringan $70^{\circ} \mathrm{C}$
$\left(\mathrm{W}_{1} \mathrm{~S}_{3}\right)$, waktu steam blanching 15 menit dengan suhu pengeringan $70^{\circ} \mathrm{C}\left(\mathrm{W}_{2} \mathrm{~S}_{3}\right)$, waktu steam blanching 20 menit dengan suhu pengeringan $60^{\circ} \mathrm{C}\left(\mathrm{W}_{3} \mathrm{~S}_{2}\right)$, waktu steam blanching 20 menit dengan suhu pengeringan $70^{\circ} \mathrm{C}\left(\mathrm{W}_{3} \mathrm{~S}_{3}\right)$ berbeda nyata dengan perlakuan waktu steam blanching 15 menit dengan suhu pengeringan $50^{\circ} \mathrm{C}\left(\mathrm{W}_{2} \mathrm{~S}_{1}\right)$ dan waktu steam blanching 20 menit dengan suhu pengeringan $50^{\circ} \mathrm{C}\left(\mathrm{W}_{3} \mathrm{~S}_{1}\right)$. Hasil rata-rata 
skoring rasa teh daun bambu Tabah dari panelis berkisar antara 3,47 sampai 4,60. Penilaian skor rasa terendah dari panelis yaitu 3,47 terdapat pada perlakuan waktu steam blanching 20 menit dengan suhu pengeringan $70^{\circ} \mathrm{C}\left(\mathrm{W}_{3} \mathrm{~S}_{3}\right)$ dengan kriteria rasa adalah cukup enak, tercium aroma teh daun bambu Tabah. Penilaian skor rasa tertinggi dari panelis yaitu 4,60 terdapat pada perlakuan waktu steam blanching 15 menit dengan suhu pengeringan $60^{\circ} \mathrm{C}\left(\mathrm{W}_{2} \mathrm{~S}_{2}\right)$ dengan kriteria rasa adalah sangat enak, aroma khas teh daun bambu Tabah. Rasa sepat yang timbul disebabkan adanya senyawa katekin. Katekin dapat memberi rasa pahit dan rasa sepat pada seduhan teh (Ramlah, 2017), sehingga semakin tinggi kandungan katekinn pada teh daun bambu Tabah maka rasa dari teh tersebut akan semakin sepat. Rusnayanti (2018) menyatakan senyawa yang berkontribusi untuk karakteristik rasa teh adalah senyawa poolifenol (katekin) dan asam amino.

\section{Uji Hedonik Teh Daun Bambu Tabah}

Berdasarkan hasil sidik ragam menunjukan bahwa perlakuan waktu steam blanching, perlakuan suhu pengeringan dan kombinasi kedua perlakuan berpengaruh sangat nyata $(\mathrm{P}<0,01)$ terhadap penerimaan keseluruhan teh daun bambu Tabah yang dilakukan dengan uji hedonik atau kesukaan. Ratarata hasil uji hedonik terhadap penerimaan keseluruhan teh daun bambu Tabah dapat dilihat pada Gambar 8.

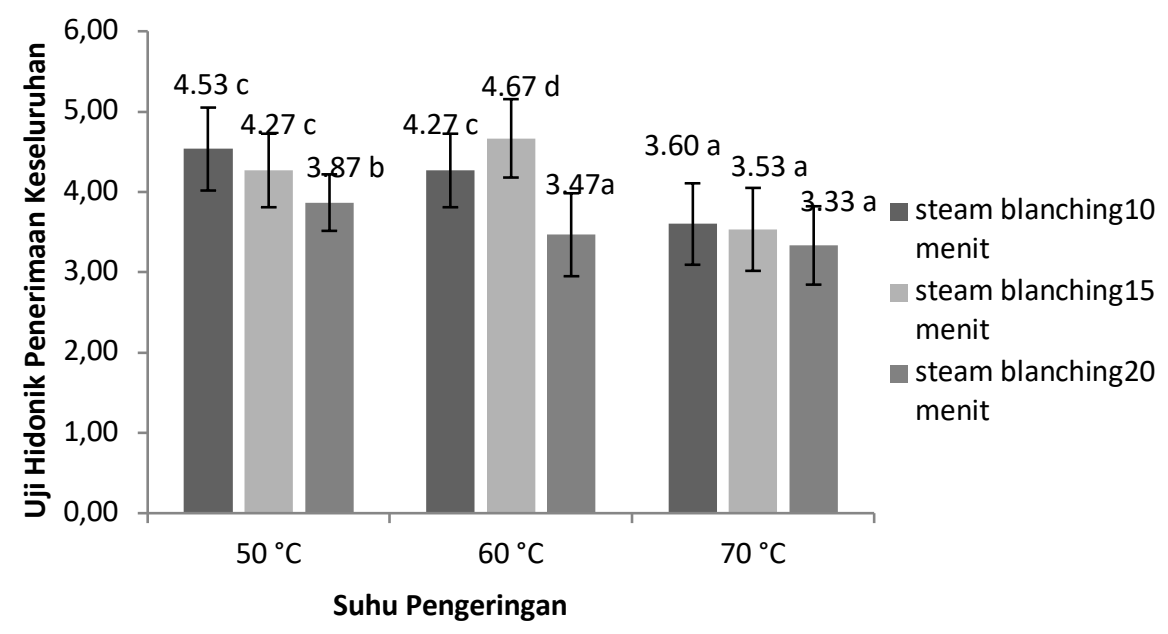

Gambar 8. Nilai rata-rata penerimaan keseluruhan teh daun bambu Tabah dari berbagai perlakuan waktu steam blanching dan suhu pengeringan. Keterangan : Huruf yang sama dibelakang nilai rata-rata yang sama menunjukan nilai yang tidak berbeda nyata berdasarkan uji BNT $(\mathrm{P}>0,05)$.

Hasil uji BNT (Beda Nyata Terkecil) menunjukan bahwa perlakuan waktu steam blanching 10 menit dengan suhu pengeringan $50^{\circ} \mathrm{C}\left(\mathrm{W}_{1} \mathrm{~S}_{1}\right)$, waktu steam blanching 10 menit dengan suhu pengeringan $60^{\circ} \mathrm{C}$ $\left(\mathrm{W}_{1} \mathrm{~S}_{2}\right)$, waktu steam blanching 15 menit dengan suhu pengeringan $50^{\circ} \mathrm{C}\left(\mathrm{W}_{2} \mathrm{~S}_{1}\right)$ berbeda nyata dengan perlakuan waktu steam blanching 10 menit dengan suhu pengeringan $70^{\circ} \mathrm{C} \quad\left(\mathrm{W}_{1} \mathrm{~S}_{3}\right)$, waktu steam blanching 15 menit dengan suhu pengeringan $70^{\circ} \mathrm{C}$ $\left(\mathrm{W}_{2} \mathrm{~S}_{3}\right)$, waktu steam blanching 20 menit dengan suhu pengeringan $60^{\circ} \mathrm{C}\left(\mathrm{W}_{3} \mathrm{~S}_{2}\right)$, waktu steam blanching 20 menit dengan suhu pengeringan $70^{\circ} \mathrm{C}\left(\mathrm{W}_{3} \mathrm{~S}_{3}\right)$ berbeda nyata dengan perlakuan waktu steam blanching 15 menit dengan suhu pengeringan $60^{\circ} \mathrm{C}\left(\mathrm{W}_{2} \mathrm{~S}_{2}\right)$ dan berbeda nyata dengan perlakuan waktu steam blanching 20 menit dengan suhu pengeringan $50^{\circ} \mathrm{C}$ $\left(\mathrm{W}_{3} \mathrm{~S}_{1}\right)$. Hasil rata-rata uji hedonik penerimaan keseluruhan teh daun bambu Tabah dari panelis berkisar antara 3,33 sampai 4,67.

Hasil hedonik penerimaan keseluruha terendah dari panelis yaitu 3,33 terdapat pada perlakuan waktu steam blanching 20 menit dengan suhu pengeringan $70^{\circ} \mathrm{C}\left(\mathrm{W}_{3} \mathrm{~S}_{3}\right)$ dengan kriteria penerimaan keseluruhan adalah cukup suka. Hasil hedonik penerimaan keseluruhan tertinggi dari panelis yaitu 4,67 terdapat pada perlakuan waktu steam blanching 15 menit dengan suhu pengeringan $60^{\circ} \mathrm{C}\left(\mathrm{W}_{2} \mathrm{~S}_{2}\right)$ dengan kriteria penerimaan keseluruhan adalah sangat suka. Penerimaan keseluruhan dipengaruhi oleh warna, aroma dan rasa seduhan teh daun bambu Tabah yang diberikan oleh panelis, sehingga semakin sepat rasa seduhan teh daun bambu Tabah dan aroma yang kurang harum khas teh bambu Tabah. Sehingga kesukaan panelis terhadap teh daun bambu Tabah akan menurun.

\section{KESIMPULAN}

Berdasarkan hasil penelitian yang telah dilakukan dapat diambil kesimpulan sebagai berikut : Perbedaan waktu steam blanching pada proses pengolahan teh daun bambu Tabah berpengaruh sangat nyata terhadap kadar air, nilai $\mathrm{pH}$, total asam, total fenol, uji 
skoring warna, uji skoring aroma, uji skoring rasa dan uji hedonik penerimaan keseluruhan.

Perbedaan suhu pengeringan pada proses pengolahan teh daun bambu Tabah berpengaruh sangat nyata terhadap kadar air, nilai $\mathrm{pH}$, total asam, total fenol, uji skoring warna, uji skoring aroma, uji skoring rasa dan uji hedonik penerimaan keseluruhan. Interaksi antara waktu steam blanching dan suhu pengeringan pada proses pengolahan teh daun bambu Tabah berpengaruh sangat nyata terhadap kadar air, nilai $\mathrm{pH}$, total fenol, uji skoring warna, uji skoring aroma, uji skoring rasa, uji hedonik penerimaan keseluruhan dan berpengaruh nyata terhadap total asam. Kombinasi perlakuan terbaik berdasarkan uji hedonik penerimaan keseluruhan yang dihasilkan pada teh daun bambu Tabah yaitu pada perlakuan waktu steam blanching 15 menit dan suhu pengeringan $60^{\circ} \mathrm{C}$ $\left(\mathrm{W}_{2} \mathrm{~S}_{2}\right)$ menghasilkan kadar air 7,03\%, nilai $\mathrm{pH} 6,40$, nilai total asam $0,94 \%$, kadar total fenol 54,95 $\mathrm{mg} / 100 \mathrm{~g}$, uji skoring warna 4,47 , uji skoring aroma 4,87, uji skoring rasa 4,60 dan uji hedonik penerimaan keseluruhan 4,67.

\section{Daftar Pustaka}

Anisah, K. 2014. Analisa Komponen Kimia dan Uji Antibakteri Asap Cair Tempurung Kelapa Sawit (Elaeis guineensis Jacq.) pada Bakteri Staphylococcus aureus Dan Pseudomonas aeruginosa.

Arpah, M. 1993. Pengawasan Mutu Pangan. Penerbit Tarsito, Bandung.

Asri, N. D. 2009. Efek Perbedaan Teknik Pengeringanterhadap Kualitas, Fermentabilitas, dan Kecernaan Hay Daun Rami (Boehmeria nivea L Gaud). Skripsi. Departemen Ilmu Nutrisi dan Teknologi Pakan. Fakultas Peternakan. Institut Pertanian Bogor.

Badan Standar Nasional. SNI 3945:2016. SNI Teh Hijau. Jakarta

Chu, D. C., \& Juneja, L. R. 1997. General chemical composition of green tea and its infusion. Chemistry and applications of green tea, 13-22.

Ciptadi, W., \& Nasution, M. Z. 1979. Mempelajari Cara Pemanfaatan Teh Hitam Mutu Rendah untuk Pembuatan Teh Dadak. Institut Pertanian Bogor.

Damayanthi, E. 2008. Studi Kandungan Katekin dan Turunannya Sebagai Antioksidan Alami Serta Karakteristik Organoleptik Produk The Mulberry dan The Camellia-Mulberry. IPB. Bogor.

Dewanto, V., Wu, X., \& Liu, R. H. 2002. Processed sweet corn has higher antioxidant activity. Journal of Agricultural and food Chemistry, 50(17), 4959-4964.

Fennema, O. R. 1996. Food Chemistry Marcel Decker. New York, NY.

Gaman, P. M., Sherrington, K. B., \& Gardjito, M. 1994. Ilmu Pangan: Pengantar Ilmu Pangan, Nutrisi dan Mikrobiologi. Gadjah Mada University Press.

Hamidah, T. 2014. Pembuatan Ekstrak Oleoresin Daun Sirih Hijau (Piper Betle L.) Sebagai Pengawet Alami (Kajian Suhu Dan Lama Waktu Ekstraksi) (Doctoral dissertation, Universitas Brawijaya).

Hartuti, N., \& Sinaga, R. M. 1997. Pengeringan cabai. Balai Penelitian Tanaman Sayuran. Pusat Penelitian dan Pengembangan Hortikultura. Badan Penelitian dan Pengembangan Pertanian.

Judoamidjojo, M., Darwis, A. A., \& Sai'd, E. G. 1992. Teknologi fermentasi. Rajawali Pers.

Kencana, P. K. D., Widia, W. And Antara, N. S. 2012. Praktek Baik Budi Daya Bambu Rebung Tabah (Gigantochloa Nigrociliata BuseKurz)', Pp. 1-69.

Kim, Y., Goodner, K. L., Park, J. D., Choi, J., \& Talcott, S. T. 2011. Changes in antioxidant phytochemicals and volatile composition of Camellia sinensis by oxidation during tea fermentation. Food Chemistry, 129(4), 13311342.

Nurhuda, H. H., Maskat, M. Y., Mamot, S., Aiq, J., \& Aminah, A. 2013. Effect of blanching on enzyme and antioxidant activities of rambutan (Nephelium lappaceum) peel. International Food Research Journal, 20(4).

Pujimulyani, D., Raharjo, S., Marsono, Y., \& Santoso, U. 2010. Pengaruh Blanching Terhadap Aktivitas Antioksidan, Kadar Fenol, Flavonoid, dan Tanin Terkondensasi Kunir Putih (Curcuma mangga Val.). Agritech, 30(3).

Ramlah, R. 2017. Penentuan Suhu dan Waktu Optimum Penyeduhan Daun Teh Hijau (Camellia Sinensis L) $\mathrm{P}+\quad 2$ Terhadap Kandungan Antioksidan Kafein, Tanin dan Katekin (Doctoral dissertation, Universitas Islam Negeri Alauddin Makassar).

Ravikumar, C. 2014. Review on herbal teas. Journal of Pharmaceutical Sciences and Research, 6(5), 236.

Roy, M. K., Juneja, L. R., Isobe, S., \& Tsushida, T. 2009. Steam processed broccoli (Brassica oleracea) has higher antioxidant activity in chemical and cellular assay systems. Food Chemistry, 114(1), 263-269.

Rusnayanti, Y. 2018. Pengaruh Suhu Dan Lama Pengeringan Terhadap Mutu Teh Hijau 
Daun Kakao (Theobroma cacao L.) (Doctoral dissertation, Universitas Mataram).

Setyaningsih, D., Apriyantono, A., \& Sari, M. P. 2010. Analisis sensori untuk industri pangan dan agro. Ciampea (ID): IPB Pr.

Sudjatha, W. Wisaniyasa. 2001. Pengantar Teknologi Pangan. Program Studi Teknologi Pertanian Universitas Udayana Denpasar.

Sutriyono, E. K. 2016. Pengaruh penambahan bubuk daun stevia (Stevia rebaudiana Bertoni $\mathrm{M}$ ) terhadap aktivitas antioksidan minuman teh hijau (Doctoral dissertation, Widya Mandala Catholic University Surabaya).

Susanti, D. Y. 2008, November. Efek suhu pengeringan terhadap kandungan fenolik dan kandungan katekin ekstrak daun kering gambir. In Prosiding Seminar Nasional Teknik Pertanian. Peran Teknik Pertanian dalam Kedaulatan Pangan dan Energi Hayati Menuju Agroindustri yang Berkelanjutan, hal (pp. 149).

Tranggono, S., Setiadji, B., \& Darmadji, P. Supranto \& Sudarmanto. 1996. Identifikasi Asap Cair Dari Berbagai Jenis Kayu Dan Tempurung Kelapa. Jurnal Ilmu dan Teknologi Pangan, 1(2), 15-24.

Tuminah, S. 2004. Teh [Camellia sinensis OK var. Assamica (Mast)] sebagai Salah Satu Sumber Antioksidan. Cermin Dunia Kedokteran, 144, 52-54.

Widjaja, E. A., Astuti, I. P., Arinasa, I. B. K., \& Sumantera, I. W. 2005. Identikit bambu di Bali. Cetakan pertama. Bidang Botani, Pusat Penelitian Biologi-LIPI. Bogor.

Winarsi, H. 2005. Antioksidan alami dan radikal. Kanisius.

Winarno, F. G. 1997. Kimia pangan gizi. Edisi Kedua. PT. Gramedia Pustaka Utama, Jakarta.

Winarno, F. G. 2002. Fisiologi lepas panen produk hortikultura. M-Brio Press, Bogor.

Winardi, R. R. 2010. Perubahan kadar flavonoid selama fermentasi seduhan teh hijau dan potensi khasiatnya. Jurnal Saintech, 2(03), 63-68.

Wood dan Lass. 1985. Jurnal Martiana Andriani "Studi Kinetika Fermentasi Pada Teh Kombucha". Fakultas Pertanian. Jurusan Teknologi Hasil Pertanian.

Zhang, Y., Bao, B., Lu, B., Ren, Y., Tie, X., \& Zhang, Y. 2005. Determination of flavone C-glucosides in antioxidant of bamboo leaves (AOB) fortified foods by reversed-phase high-performance liquid chromatography with ultraviolet diode array detection. Journal of Chromatography A, 1065(2), 177-185. 